\title{
Introduction: Toward a More Unified Libertarian Left
}

\author{
William T. Armaline ${ }^{1}$ and Deric Shannon ${ }^{2}$
}

In this introduction we briefly sketch out some of the similarities between Marxism and anarchism, particularly around the nexus often called "libertarian socialism". We argue that two contemporary trends make this a particularly good time for these kinds of bridge-building projects. First, with the economy in crisis and Leninism largely discredited, people are looking for alternatives to capitalism and state socialism and libertarian socialism provides examples of visions that are socialist, but not statist. Secondly, with the recent surge in anarchist studies - academic work rooted in anarchism - it makes sense to show some of the connections between Marxist (an already accepted perspective in academe) and anarchist theory. Finally, we map out the specific contributions in this collection of essays. [Article copies available for a fee from The Transformative Studies Institute. E-mail address:_journal@transformativestudies.org Website: http://www.transformativestudies.org (C2010 by The Transformative Studies Institute. All rights reserved.]

KEYWORDS: Libertarian Socialism, Anarchism, Marxism, Anarchist Studies.

\footnotetext{
${ }^{1}$ William Armaline is a multidisciplinary scholar activist who works primarily in the fields of sociology, education, and human rights. His areas of interest include sustainable political economic and ecological theory, critical race theory and anti-racism, critical pedagogy and transformative education, critical ethnography, inequality and youth, prison abolition, and drug policy reform. His recent publications include: (1) "What Will States Really Do for Us? The Human Rights Enterprise and Pressure from Below" (2009, Societies Without Borders, 4(3): 430-451); (2) Works on critical pedagogy and transformative education in Contemporary Anarchist Studies (2009, Routledge) and Academic Repression (2009, AK Press); (3) the upcoming book (co-editor and contributor), In Our Own Backyard: Human Rights, Injustice, and Resistance in the US (2010, UPenn. Press). Address correspondence to: William Armaline;

e-mail: warmali@yahoo.com.

${ }^{2}$ Deric Shannon is a long time anarchist living in Connecticut where he teaches sociology at the University of Connecticut. He is a co-editor of Contemporary Anarchist Studies: An Introductory Anthology of Anarchy in the Academy (Routledge 2009) and coauthor of Political Sociology: Oppression, Resistance, and the State (Pine Forge Press 2010) as well as the author of many book chapters and journal articles, typically on culture, sexuality, and radical politics. He is a member of the Workers Solidarity Alliance and a believer in radically different futures. Address correspondence to: Deric Shannon; e-mail: dericshannon@gmail.com.
} 